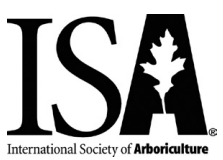

Arboriculture \& Urban Forestry 2016. 42(6): 377-388

\title{
The Cost of Not Maintaining Trees: Findings and Recommendations from an International Symposium and Summit
}

\author{
Andrew K. Koeser, Jess Vogt, Richard J. Hauer, Robert J. Northrop, \\ and Ward Peterson
}

\begin{abstract}
Urban trees are both an asset and a cost to municipalities. Past research has focused largely on the asset-quantifying and valuing the social, economic, and environmental benefits provided by trees in urban areas. Relatively fewer studies have focused on defining the appropriate level of tree care (costs or inputs) for efficiently maintaining tree health and structural integrity, and potential resulting liabilities. On 18-20 March 2015, the International Society of Arboriculture assembled a panel of research and industry experts for a research symposium and summit titled, The Costs of Not Maintaining Trees. In the weeks leading up to the summit, the Delphi technique was initiated to help build consensus on key research questions related to the economics of trees and their care. After three iterations of questions and discussion, the panel identified 14 research topics that were deemed "very important" or "important" by at least 12 of the 14 expert panelists ( $80 \%$ being a commonly used threshold for consensus). Results of this work are intended to help focus future research and funding efforts in arboriculture and urban forestry.

Key Words. Arboricultural Practices; Delphi Technique; Management Challenges; Net Benefits; Optimization; Research Summit; Stakeholder Engagement; Symposia, Urban Forest Management; Urban Tree Benefits.
\end{abstract}

Trees in urban areas are a valuable asset, both to urban residents and to municipal governments. Managers of urban forests are well aware of the ecosystem services urban trees provide. These ecosystem services include helping manage stormwater runoff (Xiao et al. 1998; Elmqvist et al. 2015; Scharenbroch et al. 2016), mitigating the urban heat island (Onishi et al. 2010), reducing air pollution (Nowak et al. 2013), sequestering carbon dioxide (Nowak and Crane 2002), increasing property values (Dimke et al. 2013) and retail sales (Wolf 2005), reducing crime (Donovan and Prestemon 2012), and benefitting human health and well-being (Nilsson et al. 2011).

Like any asset, however, urban trees also have costs. The costs of trees include those directly tied to urban forest management efforts (e.g., those resulting from the planting, maintenance, and removal of trees), repair costs (e.g., infrastructure damage or liability-related costs due to improperly planted or maintained trees), costs associated with envi- ronmental externalities (e.g., air pollution resulting from the emission of biogenic volatile organic compounds [BVOCs]), and opportunity costs (i.e., land used to plant trees cannot also be used for sidewalks, outdoor café seating, or bike lanes) (Vogt et al. 2015). These costs of trees are incurred by both urban residents and businesses located near trees, and by the municipalities frequently responsible for the planting, maintenance, and removal of street trees and park trees. Other costs include liabilities resulting from the improper planting or care of trees on public property or public right-ofway (e.g., injuries and damage from tree failure).

Any party paying for the costs of trees is inherently limited by budgetary constraints and finite resources. Urban foresters and those responsible for managing urban trees rarely have all the necessary funds they desire for the planting, maintenance, and removal of trees in the urban forest. Thus, the many benefits provided by urban trees must be weighed against the costs 
of maintaining (or not maintaining) these trees. On the surface, this comparison may seem relatively straightforward. However, the long life span of trees can make it difficult to quantify the impact of maintenance efforts on tree health and structural integrity. In order to address this challenge while highlighting the importance of efforts to quantify the benefit of tree care, the International Society of Arboriculture Science and Research Committee hosted a summit, The Costs of Not Maintaining Trees (CNMT) in Tampa, Florida, U.S., from 18-20 March 2015.

The objectives of the CNMT research summit were to:

1. Develop consensus on the most pressing needs for research on the costs and benefits of urban trees, and

2. Identify opportunities for large-scale collaborative research projects that help arborists and urban forest managers understand how to optimize urban tree maintenance and management throughout a tree's life cycle.

With regard to the second objective, two specific projects were identified-a retroactive study of past maintenance practices for communities inventoried by the same contractor, and a multi-location, planned cohort study. These are explored in greater detail in the discussion section of this paper.

\section{METHODS}

\section{Location}

The CNMT symposium and summit was held at the Patel College of Global Sustainability at the University of South Florida in Tampa, Florida, U.S. The research summit summarized in this paper was held Friday, 20 March 2015, following two days of talks by the invited panel members.

\section{Expert Panel Selection}

As with past International Society of Arboriculturesupported research symposia and summits, the CNMT event was timed with the completion of a related, contracted literature review (Hauer et al. 2015; Vogt et al. 2015). The results of this literature review were used, in part, to select an expert panel of speakers $(n=13)$. This panel, which included active researchers in the field and prac- titioners with past success in demonstrating the value of tree care in their positions, met and discussed the state of research related to urban forest costs and benefits. In addition to acknowledging their contributions to research and urban tree care, members on the expert panel were selected in an attempt to balance the following perspectives:

- International points of view: North American/non-North American

- Sectorally representative: Arboriculture and urban forestry (commercial/municipal/utility)

- Holistic costs and benefits: Environmental/ economic/social

- Basic to applied science user: Academic/ practitioner

\section{Delphi Technique}

The Delphi technique (Hsu and Sandford 2007; Yousuf, 2007; Meijering et al. 2015) was adopted to help build consensus on research priorities among the panel members prior to the summit. The Delphi technique is a means of structuring communication (e.g., use of surveys) within a group of experts in order to increase participation and work toward consensus on a given topic (Yousuf 2007). The first two rounds of questions occurred as an online survey, administered in the six weeks prior to the event. A cover letter (email) accompanied each of the two surveys. Up to two reminders were sent following the initial contact for each survey. Both pre-surveys had $100 \%$ response rates.

\section{Round 1: Open-Ended Questionnaire}

On 29 January 2015, an open-ended questionnaire was sent to all panel members. For this first round of the Delphi process (i.e., the first online survey), participants were encouraged to answer the following questions with keywords or short statements:

1. What are the core components of urban tree maintenance?

2. What are the key research questions that serve as the foundation for this summit (e.g., where should new research be focused, what persisting research gaps exist, what core assumptions/dogma require investigation)? 
3. What are the current challenges or constraints confronting efficient tree maintenance in practice/application?

4. What characteristics define successful tree maintenance?

Data from this questionnaire were assessed via qualitative data analysis using the RQDA package (Huang 2014) in R (R Core Team 2013). Responses were coded to identify common themes/topics. In assessing the list of topics, five broad categories were identified. Each topic was placed within one or more category and summary statistics were calculated to show: 1) the number of times each topics occurred across all participants; 2) the number of characters associated with each coding; and 3) the number of participants who noted a given coding. These categories and codes were then used to create network visualizations with the igraph package in R (Csardi and Nepusz 2006) to show relationships and interrelationships.

\section{Round 2: Rating Research Priorities}

On 05 March 2015, a second survey listing the 43 research questions (generated from the second question in the previous open-ended survey) was sent to the panel participants. To maintain transparency, an accompanying email was sent to provide respondents with the blinded initial responses and results of the previously detailed qualitative data analysis.

Each respondent was asked to rate the importance of the research topics on a five-point Likert scale-very unimportant (1), somewhat unimportant (2), neither unimportant or important (3), somewhat important (4), and very important (5). Research topics viewed as "very important" or "somewhat important" by more than $80 \%$ of the expert panel participants were deemed research priorities by consensus (Hsu and Sandford 2007). An additional participant was identified by members of the summit panel and joined the summit for this stage $(\mathrm{n}=14)$. As such, 12 participants were needed to meet the $80 \%$ threshold. Results were tallied in a summary table that included the following: the research topics; the percent of participants rating the topic "very important"; the percent of participants rating the topic "somewhat important"; and the ranking of the topic (based on the sum of individual responses to Likert-scale ratings, where "very important" = 5). This summary table was distributed to the summit participants prior to the event.

\section{Round 3: Research Summit}

The final iteration of this consensus building process was the face-to-face summit. Participants were asked to provide feedback on the rankings of research priorities obtained from Round 2. Beyond this final stage in consensus building, participants were encouraged to identify projects and testable hypotheses for the top research statements selected through the Delphi process (second objective). As part of this exercise, participants were instructed to think about potential collaborators, funding sources, and other partners. The results of these discussions are highlighted hereafter, along with the earlier survey findings.

\section{RESULTS}

\section{Round 1: Open-Ended Questionnaire}

Five broad categories emerged, given the topics generated by the four open-ended questions from the first survey; the categories were loosely related to the individual questions posed. These categories were: 1) urban forest management, 2) management practices, 3) management challenges, 4) costs and benefits, and 5) stakeholder involvement (Figure 1).

When asked about the core components of urban tree management, six management practices were commonly noted by the panelists (management practices; Figure 1). These practices included: risk management (9 of 13); inventorying ( 6 of 13, with one-third of these respondents emphasizing remote-sensing technologies); planting/early care (6 of 13); pruning (6 of 13); root and soil management (5 of 13); and pest management ( 4 of 13). Additionally, 4 of the 13 respondents noted the need to identify the appropriate dosage (i.e., frequency, intensity, and duration) of maintenance practices when attempting to increase tree longevity and maximize net benefits. Similarly, 7 of 13 respondents stressed the need for measurable goals and objectives when prescribing urban forest management strategies.

When listing constraints and challenges that limit efficient tree care and manage- 


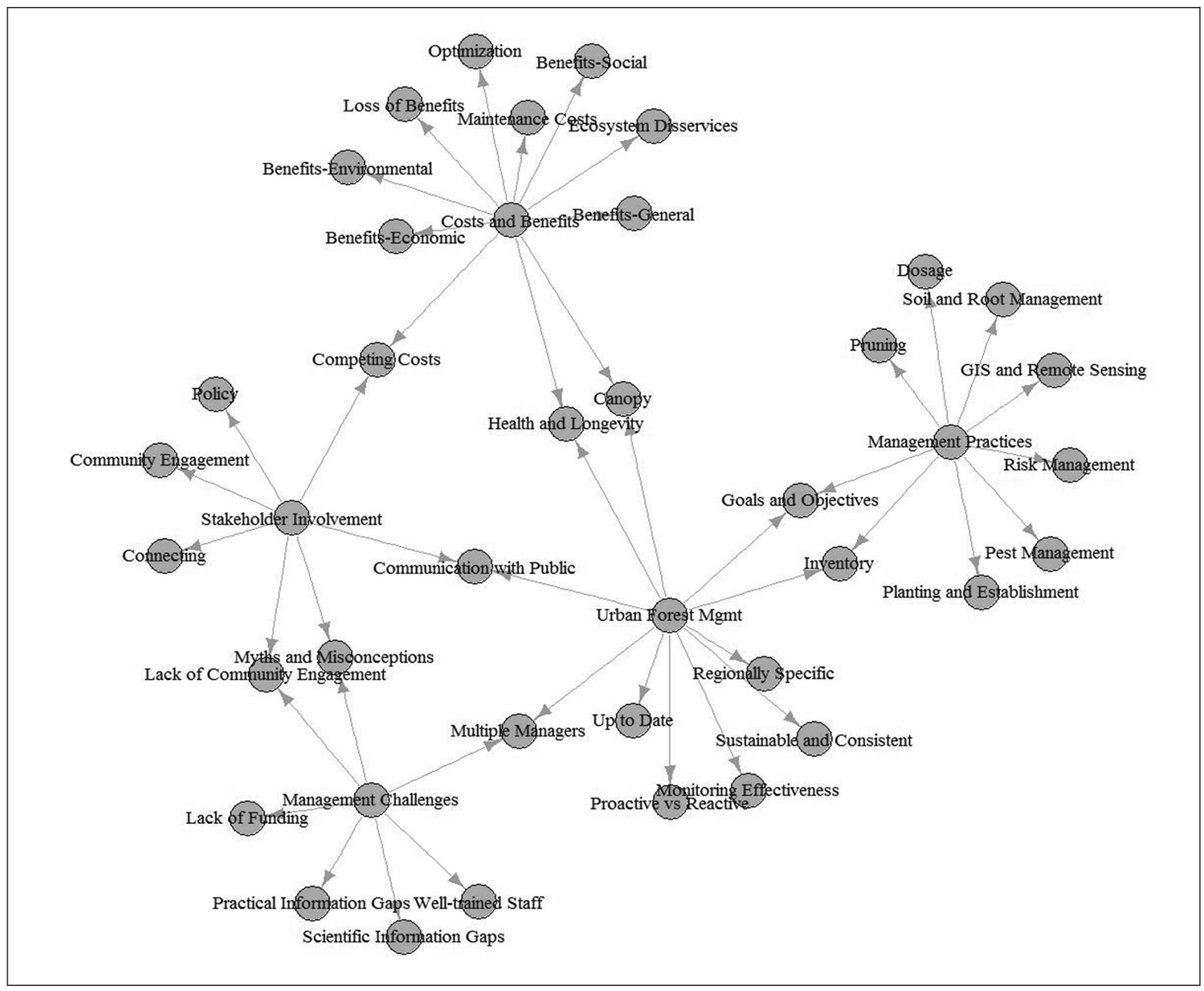

Figure 1. Common topics and categories of urban tree management identified during the open-response questionnaire. The five main categories outlined below are: 1) urban forest management, 2) management practices, 3) management challenges, 4) costs and benefits, and 5) stakeholder involvement.

ment, the three most commonly reported concerns among the panel included: the absence of well-trained staff (6 of 13 respondents), lack of sustained and appropriate funding (5 of 13 respondents), and the lack of practical information (e.g., baseline inventory data, disease pressure maps; 5 of 13 respondents). Another concern related to training and education was the reliance on myth and dogma (as opposed to research) in determining what practices are appropriate for tree care (3 of 13 respondents). While nine respondents noted that community engagement was a core component of successful tree maintenance, only one respondent noted lack of engagement as a concern or constraint.
When asked to characterize successful tree maintenance efforts, respondents noted that such efforts maximize tree health and longevity (8 of 13 respondents) and optimize resources allocated to the planting and care of trees ( 8 of 13 respondents). Clear goals and measurable objectives were seen as an important means of guiding tree care practice (7 of 13 respondents), while also serving as benchmarks for the critical (though sometimes overlooked) monitoring stage of urban forest management (7 of 13 respondents). Respondents also noted that successful tree maintenance works to engage (6 of 13 respondents), connect (5 of 13 respondents), and communicate (4 of 13 respondents) with the community and other stakeholders. 


\section{Round 2: Rating Research Priorities}

Panelists agreed on 14 of the 43 research priorities generated during the first round of the Delphi process (Table 1). Not surprisingly, 4 of the top 5 research topics were variations of the theme of the symposium and could easily be aggregated into a single research question (Table 1). The underlying theme involved the economic costs and benefits that result from undertaking a particular maintenance practice (e.g., pruning, reactive versus proactive) and how this could be measured (e.g., the marginal impact of performing a maintenance activity as it yields a return on investment, change in tree condition/health, improved infrastructure). Other topics viewed as important focused on missing information regarding benefits to human health and wellbeing, the long-term impacts of pruning and early tree care, and the impact of siterelated factors on tree survival (Table 1).

\section{Round 3: Research Summit}

At the summit, no changes were made to the topics listed in Table 1. A motion was made to further consolidate the topics into two key areas of research: 1) tree benefits and 2) the costs and benefits of urban tree care and management. Once noted, these two themes guided the

Table 1. Tree maintenance research topics deemed important by consensus of an expert panel (rated either "very important" or "somewhat important" by $80 \%$ or more of the summit participants ( 12 of 14$)$. Rankings based on the sum of the associated Likert-scale scores for each research topic.

\begin{tabular}{|c|c|c|c|}
\hline Research topic & $\begin{array}{l}\text { Number }(\%) \\
\text { "very important" }\end{array}$ & $\begin{array}{l}\text { Number (\%) } \\
\text { "somewhat important" }\end{array}$ & $\begin{array}{l}\text { Sum of individual } \\
\text { scores (ranking) }\end{array}$ \\
\hline $\begin{array}{l}\text { Identifying optimal maintenance regime for various management goals (cost } \\
\text { versus benefit) }\end{array}$ & $11(79 \%)$ & $3(21 \%)$ & $67(1)$ \\
\hline Calculating the economic return on investment for various maintenance practices & $9(64 \%)$ & $5(36 \%)$ & $65(2)$ \\
\hline $\begin{array}{l}\text { Identifying the costs of not maintaining trees (e.g. reduced benefits, built } \\
\text { infrastructure costs, etc.) }\end{array}$ & $10(71 \%)$ & $3(21 \%)$ & $62(3)$ \\
\hline $\begin{array}{l}\text { Comparison of reactive vs. proactive/systematic maintenance efforts with } \\
\text { regard to costs, benefits, tree health/condition, and urban tree longevity }\end{array}$ & $8(57 \%)$ & $5(36 \%)$ & $60(4)$ \\
\hline $\begin{array}{l}\text { Collecting/finding data that supports or refutes maintenance practices currently } \\
\text { accepted by the industry }\end{array}$ & $8(57 \%)$ & $5(36 \%)$ & $60(4)$ \\
\hline $\begin{array}{l}\text { Assessing the impact of structural pruning (frequency, intensity, duration, etc.) } \\
\text { on tree longevity and failure potential }\end{array}$ & $7(50 \%)$ & $6(43 \%)$ & $59(5)$ \\
\hline $\begin{array}{l}\text { Identifying the level in which urban trees influence socio-economic factors } \\
\text { (e.g., neighborhood property values, crime rates, community involvement, } \\
\text { and risk) }\end{array}$ & $6(43 \%)$ & $7(50 \%)$ & $58(6)$ \\
\hline $\begin{array}{l}\text { Determining the "dosage" of urban greening that is required to provide various } \\
\text { benefits to human health and well-being }\end{array}$ & $3(21 \%)$ & $10(71 \%)$ & $55(7)$ \\
\hline Calculating the true costs of tree maintenance from production to removal/disposal & $7(50 \%)$ & $5(36 \%)$ & $55(7)$ \\
\hline $\begin{array}{l}\text { Determining the optimal dosage (frequency, intensity, duration, etc.) of } \\
\text { maintenance practices like irrigation, pruning, pest management, etc. }\end{array}$ & $6(43 \%)$ & $6(43 \%)$ & $54(8)$ \\
\hline $\begin{array}{l}\text { Identifying ways to effectively initiate and sustain communication/engagement } \\
\text { with the community }\end{array}$ & $6(43 \%)$ & $6(43 \%)$ & $54(8)$ \\
\hline $\begin{array}{l}\text { Identifying the minimum level of care required to reduce transplant loss/early } \\
\text { mortality to acceptable levels }\end{array}$ & $1(7 \%)$ & $12(86 \%)$ & $53(9)$ \\
\hline $\begin{array}{l}\text { Developing ways to effectively show the connection between the maintenance } \\
\text { of individual trees and higher-level policy goals }\end{array}$ & $7(54 \%)^{z}$ & $4(31 \%)^{z}$ & $51(10)$ \\
\hline Assessing the impact of site conditions/region on growth and survival of trees & $2(14 \%)$ & $10(71 \%)$ & $50(11)$ \\
\hline
\end{tabular}

${ }^{2}$ Includes one non-respondent. 
remainder of the face-to-face discussions. The latter theme ultimately became the core question for two research initiatives spurred by the summit.

\section{DISCUSSION}

The remainder of this paper captures the panel's discussions of identified key areas of research (i.e., tree benefits and the costs and benefits of urban tree care). In addition, two specific research proposals outlined by the panel serve as future steps for assessing the long-term costs and benefits of urban tree care. This section concludes with a discussion of the importance of identifying the cause of death, in research related to tree longevity and care. The topic was discussed at length by the participants and is included here for the benefit of those not present at the summit.

\section{Tree Benefits}

Tree benefits are quantified as a means of showing the value of trees when communicating with the public and to policy makers. Monetary values are often given for multiple benefits [e.g., through use of i-Tree software (i-Tree 2016)] as a means of comparison with other services and infrastructure funded by municipalities. During the summit discussions, a member of the panel noted that promoted benefits must connect analytically/ technically, economically, emotionally, and/ or historically with an intended audience to be effective tools for supporting urban tree care. Past research on ecosystem services has primarily addressed issues that appeal to analyticallyand technically-minded individuals. Social and health benefits are less studied and are often difficult to monetize in a manner that is widely accepted. This lack of research was noted by the summit participants. In working to identify limitations of current tree benefit calculators, nearly half of the deficiencies noted were related to social and health issues (Figure 2).

\section{The Costs and Benefits of Tree Care Activities}

Tree care activities are undertaken with the presumption that they will have a positive impact on tree health and (ultimately) urban forest structure (Figure 3). Examples of tree care activities include: watering trees at planting to improve tree survival, structurally pruning trees to improve form at a young age and increase resiliency to storms, and treating trees to protect trees from a lethal pest. Their effectiveness aside, these practices have costs that can be enumerated at the time the maintenance is conducted. These costs are weighted against presumed outcomes or benefits. In measuring the composition and structure of the urban forest, a range of benefits can be calculated and, in some cases, monetized.

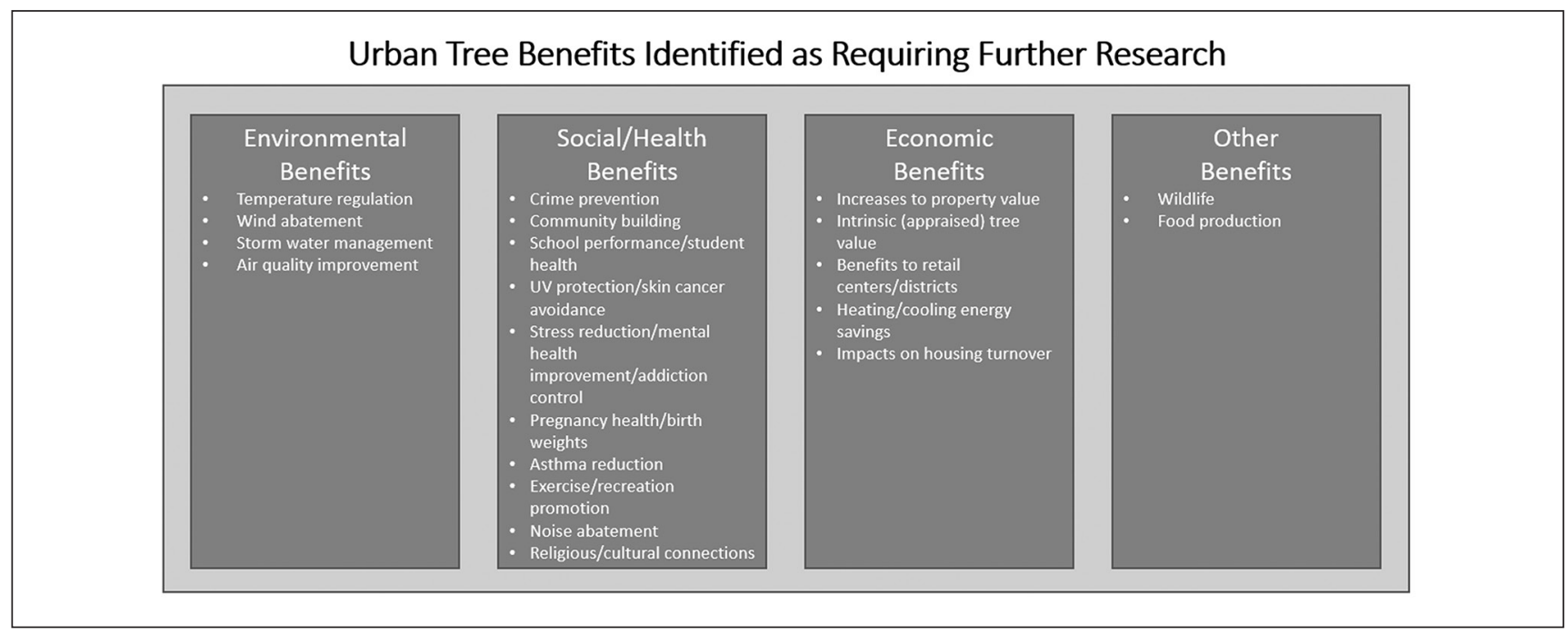

Figure 2. Urban tree benefits identified as requiring additional research at the face-to-face meeting (third Delphi iteration) at the Cost of Not Maintaining Trees Summit in Tampa, Florida, U.S. Benefits were grouped under one of four categories: 1) environmental benefits, 2) social/health benefits, 3) economic benefits, and 4) other benefits. 
The benefits of tree maintenance could include greater service life of the tree and an increase in its associated ecosystem benefits, decreased tree limb breakage and storm cleanup in the future, or enhanced tree longevity and a reduction in urban forest removal and planting costs. The fundamental question with any of these practices is whether the marginal benefit resulting from the maintenance exceeds the marginal cost. The accounting of benefits and costs can involve many variables, each of which require itemization and price assignment over a common time period and ideally consider the changing value of money over time. After this is all considered, a decision could be made that the benefits exceeds the costs (or not), using one of several evaluation mechanisms, such as net benefit (benefits minus costs, annualized or cumulative), net present value (sum of discounted benefits minus discounted costs), benefit-cost ratio (benefits divided by costs), internal rate of return (the discounted interest rate when net present value $=0$ ), or other approach (Miller et al. 2015). collected and the time frame required. Discipline and organization are required when keeping and tracking cost information over time. Once collected, the data must be analyzed appropriately to quantify costs and benefits. This can quickly become a complicated undertaking. Standardizing maintenance definitions, practices, and data collection activities is also important. Simply reporting that a tree was pruned does not convey how the tree was pruned, the intensity of pruning, the pruning objectives, who performed the work, and the price (i.e., cost) of the work.

Further, accounting for the benefits of trees during their life cycle is complex. The marketplace gives the value of what a person is willing to pay for something. This could be something tangible, like a pruning services, or something more subjective, like the value a person places on a tree as part of their quality of life. Where a marketplace of buyers and sellers does not exist, data gatherers can use other methodological approaches as surrogates to place value on assets. Examples of such methods include those that use hedonic pricing to determine the monetary

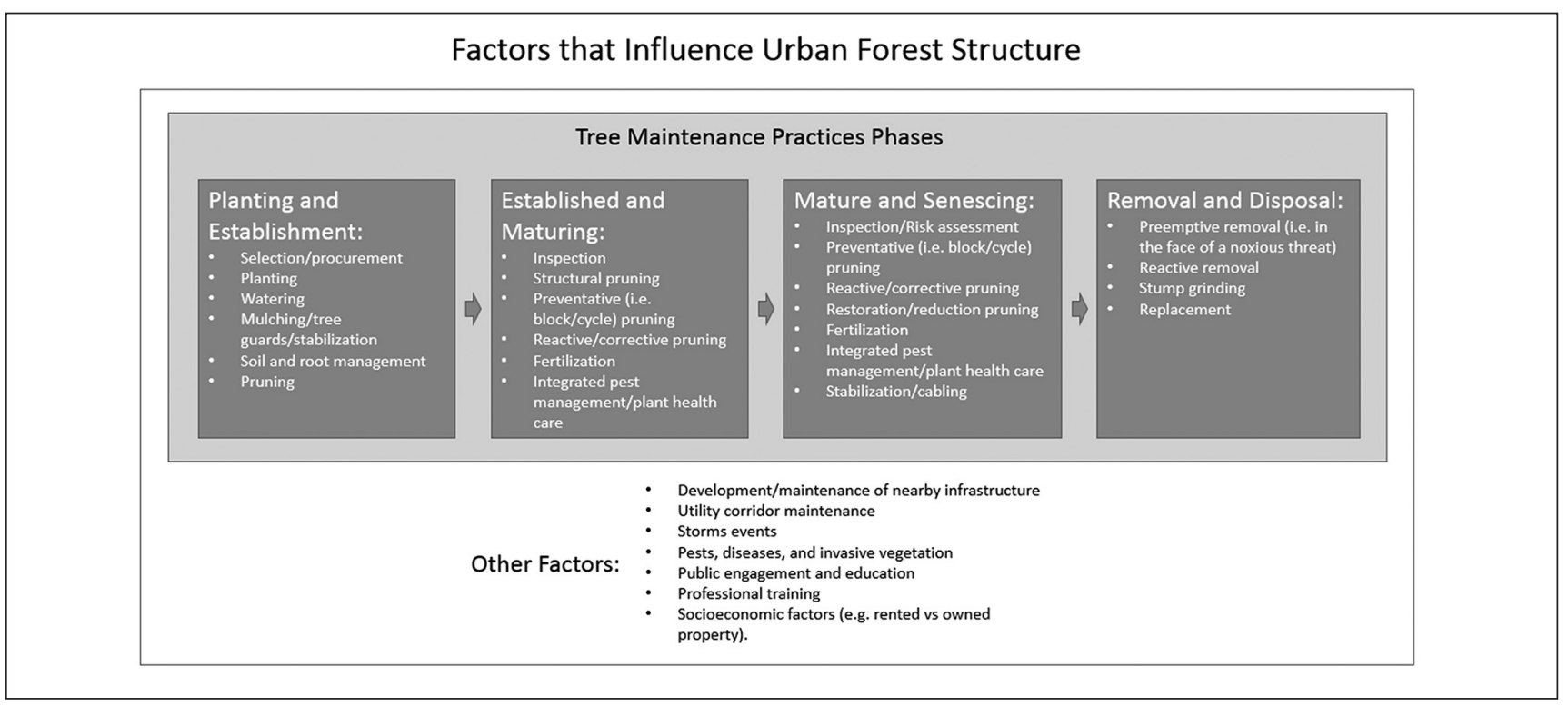

Figure 3. Key components of urban tree maintenance periodicity and factors that potentially influence tree growth and longevity and urban forest structure.

In theory, documenting the benefits and costs of the urban forest is merely an accounting and financial exercise. In practice, tracking every cost requires defining what information needs to be impact of a tree on property values, the ecological and societal benefits of trees (e.g., using software such as i-Tree), or deriving a compensatory value of a tree using a formula [e.g., such 
as the Council of Tree and Landscape Appraisers Trunk Formula Method (CTLA 2000)].

\section{Future Steps in Assessing the Costs of Not Maintaining Trees}

One of the main objectives of the summit was to identify opportunities for large-scale collaborative research projects. Over the course of the discussions, two key projects were outlined by the expert panel. They were a retroactive study of past maintenance efforts (drawing on maintenance records and inventory data) and the creation of a multi-site cohort study. Both studies vary in their potential benefits and limitations with regard to assessing whether past/ current industry maintenance practices truly increase tree growth and longevity. These studies are detailed in the remainder of this paper.

\section{Proposed study 1: Retroactive study of past maintenance efforts}

Long-term studies regarding the impacts of past tree care practices on an urban tree population are limited (Hauer et al. 2015; Vogt et al. 2015). Compared to other research subjects, such as animals, trees are organisms with perennial and indeterminate growth of length and girth, and have the potential to be very long-lived organisms (Pallardy 2008). Tree maintenance practices are subject to lag effects; often the outcome of a given treatment or management practice does not fully manifest until years after it has been applied. As an example, the avoidance of structural pruning at a young age may result in branch inclusions that result in unacceptable tree risk several decades later (Clark and Matheny 2010). Likewise, improper flush-cut pruning may result in greater tree decay that doesn't visually manifest for years (Clark and Matheny 2010). This multi-decade timeframe is nearly always beyond the scope of most academic research projects and funding sources.

Retroactive studies that draw on historical management records can offer a long-term perspective on the impact of tree care activities while staying within the bounds of an academic time line. These studies are not without their challenges. Finding quality data that have been maintained continually can be difficult. Urban trees are planted, grow, and die. If a tree inventory does not fully follow how tree cohorts change due to these life events, incomplete information can lead to inaccurate conclusions. Since municipal operating budgets can rise and diminish due to changes in internal politics and external economic pressures, in periods of budgetary shortfall, urban forest inventory and data collection efforts may slow or stop as operations become largely reactive in nature and collecting tree data becomes a lower priority. Even with sustained support, data collection methods and data collectors may change, causing data quality to vary over time and across locations. Adding to this variability, maintenance activities like pruning (e.g., flush-cut versus branch-collar pruning; or structural pruning that may mean lion's tailing to an arborist entering a work force several decades ago) and planting have evolved over time as research and industry consensus redefine proper practice. Further, the lack of a common data collection standards affects the ease of a longitudinal study from multiple locations.

When these factors are considered, and incomplete or overly noisy data sets are removed from consideration, the list of possible sites for retroactive studies based on historical management records becomes smaller with decreased applicability. The proportion of these sites that are "known" to researchers interested in assessing the long-term impacts of tree care is even smaller. As such, there was genuine interest from researchers, during the summit, when panelists from The Davey Tree Expert Company noted they had been contracted to inventory and provide maintenance recommendations for six municipalities in California (United States) for nearly three decades. While assessors changed with time and additional data were collected on some sites, the core data set was collected in a consistent manner with standardized definitions for tree/site attributes and prescribed management actions, due to the continuity of having a single urban forest management company (Davey) in the employ of each municipality for a relatively long period. The potential data source immediately piqued the interest of other panelists from the United States Department of Agriculture Forest Service and several universities. By the end of the meeting, a research team had been formed 
and efforts put underway to gain the permission of these cities to use their data for a pilot study that could help elucidate important variables for a long-term, multi-location cohort study.

\section{Proposed Study 2: Multi-location Cohort Study}

Long-term health and longevity studies can be designed (e.g., cohort) or observational (e.g., retroactive study). The six-community study previously described is similar to a retroactive epidemiological study on human health (Ahrens et al. 2014). In addition to epidemiology, medical researchers and public policy analysts (mindful of many of the issues noted here) sometimes design and conduct long-term cohort studies to test the impacts of various treatments, behaviors, or external factors on a group of subjects over time. This allows the researchers to truly standardize data collection and even prescribe "interventions" (e.g., a stress management program) to a subset of the sample populations.

A long-term cohort study of the impacts of tree maintenance on tree longevity and condition would allow more control over the species included, maintenance conducted, and measurements taken. Still, there are some significant logistical considerations associated with such an undertaking. Working with a single location would be the easiest approach; however, findings may be limited to that city or cities with similar environmental and socio-cultural growing conditions, species profiles, source nurseries and planting stock, and management objectives. Working with multiple sites would require some cities to modify their existing inventories and perhaps their tree planting and care practices (unless the sites chosen have a similar inventory and maintenance contractor, like the six cities from the retroactive study in California). Beyond data, the tree work conducted would need to be standardized via thorough and understandable specification of arboricultural practices. Finally, the sites would need to have a significant planting program (or the ability to coordinate one) to provide the necessary sample size. For a cohort study to be successful, the trees included would need to be studied over their whole life span, from planting to removal. Starting with a group of trees already present may yield a biased sample, as the trees have all survived the stress of transplanting.

While noting the challenges associated with conducting a long-term, multi-site cohort study (e.g., cost, standardization of data collection, commitment of all individuals and groups involved), many in the panel believed the benefits offered by this approach warranted further investigation. While trained arborists and urban foresters may maintain trees according to industry standards and best management practices, there is often limited research showing this work improves tree health and survival over the long term. Unless a robust, long-term assessment is conducted, urban forest managers and arborists can only infer that practices tested through short-term assessments will result in greater urban tree growth and longevity.

Several members within the expert panel left the summit committed to pursuing this cohort research question further. Many cities like Milwaukee, Wisconsin, U.S. (Koeser et al. 2013; Sivyer 2015) and New York City, New York, U.S. (Lu et al. 2010; Barrick 2015) have proactive inventorying, planting, and management programs. The urban foresters present at the summit noted it would not be difficult to adjust inventorying parameters/methods to a more standardized format. Others noted that efforts were already underway to standardize urban tree inventory data collection though an initiative led by the Arboricultural Research and Education Academy Urban Tree Growth and Longevity working group (Leibowitz 2012; McPherson and Roman 2012).

Using the findings from the retroactive study proposed herein (and others) as pre-proposal data, the group intends to pursue larger funding sources (e.g., National Science Foundation, European Union) to establish an array of urban forest long-term social-ecological observatories to track the long-term benefits and costs of tree care over time (e.g., reduced service calls, increased property value, avoided maintenance costs over time). These sites would be cities with an existing commitment to urban forestry that have ties to research institutions (e.g., research centers, universities, arboretums). While this would likely limit the sample to sites with more actively managed urban forests, the participating cities would 
be best able to provide the long-term data critically needed to assess the effects of planting, pruning, and risk management efforts over time.

\section{The Importance of "Cause Of Death" in Cohort Studies}

One bit of data that was identified as being extremely useful for cohort studies, but is often beyond the scope of most inventory efforts, is the cause of death in a tree. While this is often difficult to assess if an inventory happens several months or years after a tree dies or is removed, there are some factors that could be recorded at the time of removal/re-measurement. These include:

- death by an identifiable, noxious pest/disease (e.g., emerald ash borer, Texas Phoenix palm decline, abiotic disorder)

- removal to mitigate a risk

- removal/death given a conflict with construction or development

- removal because the species was invasive

- removal by resident request

- death given storm damage failure

- death given site constraints (undersized planting space)

- vandalism or other mechanical damage beyond repair

These data would allow researchers to filter out trees that die or are removed for reasons unrelated to structural integrity or vitality (e.g., removed because the homeowner didn't like the seed pods in his or her yard). With this external noise controlled, researchers would be better able to identify factors and treatment practices that accurately predict plant survival.

\section{CONCLUSION}

The cost of maintaining trees is as important as the benefits received, when evaluating the effectiveness of urban forest management. Though somewhat hidden, the costs of not maintaining trees are likely a significant component of the true costs of urban greening. As researchers and practitioners learn more of how specific maintenance practices affect the longevity, safety, and cost and benefits of trees, individuals will be better equipped to manage trees in the urban forest and make trees in their communities more abundant and appreciated.
The CNMT summit brought together leading academics, researchers, and practitioners to identify key research needs with regard to the costs and benefits of urban tree management. These summarized findings are intended to help focus future research and funding efforts for those addressing this field of research. Through surveys and open discussions, six management practices were identified as core components of urban tree care. These included: identifying optimal maintenance regime for various management goals (cost versus benefit); calculating the economic return on investment for various maintenance practices; identifying the costs of not maintaining trees (e.g. reduced benefits, built infrastructure costs); comparing reactive versus proactive/systematic maintenance efforts with regard to costs, benefits, tree health/condition, and urban tree longevity; and assessing the impact of structural pruning (frequency, intensity, duration) on tree longevity and failure potential.

More importantly, the two projects outlined at the CNMT summit serve as a blueprint for real, actionable science designed to help separate tree care practices that benefit trees from the larger range of activities believed to increase tree growth and longevity. A retroactive study of past maintenance efforts and a multi-locational cohort study were explored and recommended as research projects that could start answering questions regarding the efficacy and cost-effectiveness of past and current maintenance practices. Initial research pilot projects will illustrate the value of structured, cohort research and may attract larger funding sources and more partners.

Acknowledgments. This combined symposium and summit was made successful through a partnership with ISA, the ISA Florida Chapter, the Florida Urban Forestry Council, the Patel College of Global Sustainability at the University of South Florida, and the University of Florida IFAS Extension. The authors would like to thank the following organizations for their financial support of the Cost of Not Maintaining Trees Symposium and Summit: The Florida Forest Service, the International Society of Arboriculture Science and Research Committee, the Davey Institute at the Davey Tree Expert Company; Bartlett Tree Experts, the Center for Landscape Conservation and Ecology at the University of Florida, and the Arboricultural Research and Education Academy. 


\section{LITERATURE CITED}

Ahrens, W., K. Krickeberg, and I. Pigeot. 2014. pp. 3-41. An Introduction to Epidemiology. In: W. Ahrens and I. Pigeot (Eds.). Handbook of Epidemiology. Springer, New York, U.S.

Barrick, J. 2015. New York City Case Study. Presentation at the International Society of Arboriculture Cost of Not Maintaining Trees Symposium. Tampa, Florida, United States. 19 March 2015.

Clark, J.R., and N. Matheny. 2010. The research foundation to tree pruning: A review of the literature. Arboriculture \& Urban Forestry 36(3):110-120.

Csardi, G., and T. Nepusz. 2006. The igraph software package for complex network research. InterJournal, Complex Systems 1695(5):1-9.

Council of Tree \& Landscape Appraisers (CTLA). 2000. Guide for Plant Appraisal, ninth edition. International Society of Arboriculture. Champaign, Illinois, U.S. 143 pp.

Dimke, K.C., T.D. Sydnor, and D.S. Gardner. 2013. The effect of landscape trees on residential property values of six communities in Cincinnati, Ohio. Arboriculture \& Urban Forestry 39(2):49-55.

Donovan G.H., and J.P. Prestemon. 2012. The effect of trees on crime in Portland. Environment and Behavior 44(1):3-30.

Elmqvist, T., H. Setälä, S.N. Handel, S. van der Ploeg, J. Aronson, J.N. Blignaut, E. Gómez-Baggethun, D.J. Nowak, J. Kronenberg, and R. de Groot. 2015. Benefits of restoring ecosystem services in urban areas. Current Opinion in Environmental Sustainability $14: 101-108$.

Hauer, R.J., J.M. Vogt, and B.C. Fischer. 2015. The cost of not maintaining the urban forest. Arborist News 24(1):12-17.

Hsu, C., and B.A. Sandford. 2007. The Delphi technique: Making sense of consensus. Practical Assessment, Research \& Evaluation 12(10). Accessed 09 March 2015. <http://pareonline.net/ getvn. $a s p ? \mathrm{v}=12 \& \mathrm{n}=10>$.

Huang, R. 2014. RQDA: R-based Qualitative Data Analysis. R package version 0.2-7. Accessed on March 9, 2015. <http://rqda.r-forge.rproject.org $>$.

i-Tree. 2016. i-Tree management software. USDA Forest Service. $<$ www.itreetools.org>

Koeser, A.K., R. Hauer, K. Norris, and R. Krouse. 2013. Factors influencing long-term street tree survival in Milwaukee, WI, USA. Urban Forestry \& Urban Greening 12(4):562-568.

Leibowitz, R. 2012. Urban tree growth and longevity: An international meeting and research symposium white paper. Arboriculture \& Urban Forestry (38(5):237-241.

Lu, J.W.T., E.S. Svendsen, L.K. Campbell, J. Greenfeld, J. Braden, K. King, and N. Falxa-Raymond. 2010. Biological, social, and urban design factors affecting young street tree mortality in New York City. Cities and the Environment 3(1):1-15.

McPherson, E.G., and L. Roman. 2012. Urban Tree Monitoring: Opportunities for Research and Management. 2012 International Society of Arboriculture Annual Conference and Trade Show, Portland, Oregon, 11-15 August 2015.

Meijering, J.V, H. Tobi, A. van den Brink, and F. Morris. 2015. Exploring the research priorities in landscape architecture: An international Delphi study. Landscape and Urban Planning 137:85-94

Miller, R.W., R.J. Hauer, and L.P. Werner. 2015. Urban Forestry: Planning and Managing Urban Greenspaces, third edition. Waveland Press. Long Grove, Illinois, U.S. 560 pp.
Nilsson, K., M. Sangster, C. Gallis, T. Hartig, S. De Vriew, K. Seeland, and J. Schipperijn (Eds.). 2011. Forest, Trees, and Human Health. Springer, New York, U.S.

Nowak, D.J., and D.E. Crane. 2002. Carbon storage and sequestration by urban trees in the USA. Environmental Pollution 116: 381-389.

Nowak, D.J., S. Hirabayashi, A. Bodine, and R. Hoehn. 2013. Modeled PM2.5 removal by trees in ten U.S. cities and associated health effects. Environmental Pollution 178:395-402.

Onishi A., X. Cao, T. Ito, F. Shi, and H. Imura. 2010 Evaluating the potential for urban heat-island mitigation by greening parking lots. Urban Forestry \& Urban Greening 9:323-332.

Pallardy, S. 2008. Physiology of Woody Plants, third edition. Academic Press, Burlington, Massachusetts, U.S. 454 pp.

R Core Team. 2013. R: A language and environment for statistical computing. R Foundation for Statistical Computing, Vienna, Austria. Accessed on March 9, 2015. <www.R-project.org>

Scharenbroch, B.C., J. Morgenroth, and B. Maule. 2016. Tree species suitability to bioswales and impact on the urban water budget. Journal of Environment Quality 45:199-206.

Sivyer, D. 2015. Milwaukee Case Study. Presentation at the International Society of Arboriculture Cost of Not Maintaining Trees Symposium. Tampa, Florida, United States. 19 March 2015.

Vogt, J.M., R.J. Hauer RJ, and B.C.Fischer 2015 The costs of maintaining and not maintaining trees: A review of the urban forestry and arboriculture literature. Arboriculture \& Urban Forestry 41(6):293-323.

Wolf, K.L. 2005. Business district streetscapes, trees, and consumer response. Journal of Forestry 103:396-400.

Xiao Q., E.G. McPherson, J.R. Simpson, and S.L. Ustin. 1998. Rainfall interception by Sacramento's urban forest. Journal of Arboriculture 24(4):235-244.

Yousuf, M.I. 2007. Using experts' opinions through Delphi technique. Practical Assessment Research \& Evaluation 12(4). Accessed 09 March 2015. <http://pareonline.net/getvn. asp? $v=12 \& n=4>$. 


\author{
Andrew K. Koeser (corresponding author) \\ Assistant Professor \\ Department of Environmental Horticulture, CLCE, IFAS \\ University of Florida - Gulf Coast Research and Education \\ Center \\ 14625 County Road 672 \\ Wimauma, Florida 33598, U.S.
}

Jess Vogt

Assistant Professor

Department of Environmental Science and Studies

DePaul University

1 E. Jackson

Chicago, Illinois 60604, U.S.

\author{
Richard J. Hauer \\ Professor \\ College of Natural Resources \\ University of Wisconsin-Stevens Point \\ 800 Reserve Street \\ Stevens Point, Wisconsin 54481, U.S.
}

Robert J. Northrop

Extension Forester

University of Florida/IFAS - Hillsborough County Extension

5339 County Road 579

Seffner, Florida 33584, U.S.

\author{
Ward Peterson \\ Manager \\ Davey Resource Group \\ 1500 N Mantua St. \\ Kent, Ohio, U.S
}

Résumé. Les arbres urbains représentent à la fois un atout et un coût pour les municipalités. Les recherches antérieures ont porté en grande partie sur les atouts soit la quantification et la valorisation des avantages sociaux, économiques et environnementaux que procurent les arbres dans les zones urbaines. Un nombre moindre d'études ont porté sur la définition du niveau approprié de soins aux arbres requis (coûts ou intrants) afin de maintenir de manière efficace la santé des arbres, leur intégrité structurelle et les responsabilités potentielles qui en découle. Du 18 au 20 mars 2015, l'International Society of Arboriculture a rassemblé un comité de spécialistes provenant de la recherche et de l'industrie pour un symposium sur la recherche et un sommet intitulé "Les coûts du non entretien des arbres ». Dans les semaines précédant le sommet, la méthode Delphi a été appliquée afin d'aider à établir un consensus sur les questions essentielles liées aux facteurs économiques des arbres et à leur entretien. Après trois séances de questions et de discussions, le groupe a identifié 14 sujets de recherche qui ont été considérés comme "très important " ou "important " par au moins 12 des 14 membres constituant le comité d'experts ( $80 \%$ étant un seuil généralement utilisé pour la reconnaissance d'un consensus). Il est souhaité que les résultats de ces travaux aideront à orienter les recherches futures ainsi que leur financement en arboriculture et en foresterie urbaine.
Zusammenfassung. Urbane Bäume sind sowohl ein Gewinn als auch ein Kostenfaktor für ihre Kommune. Die vorangegangene Forschung fokussierte größtenteils auf dem Gewinn - sie quantifiziert und bewertet die sozialen, ökonomischen und ökologischen Vorteile, die durch Bäume in urbanen Räumen entstehen. Relativ wenige Studien fokussieren auf die Definition eines angemessenen Grads an Baumpflege (Kosten oder Aufwand), um effizient die Baumgesundheit und die strukturelle Integrität zu erhalten, sowie auf die daraus möglich resultierenden Haftungsfragen. Die ISA versammelte ein Podium mit Experten aus Forschung und Industrie für ein Forschungssymposium und Gipfeltreffen unter dem Namen: „Die Kosten von nicht unterhaltenen Straßenbäumen“. In den Wochen vor dem Gipfeltreffen wurde die Delphi-Technik initiiert, um einen Konsens über Schlüsselfragen in der Forschung in Bezug auf die Ökonomie der Bäume und ihre Pflege zu finden. Nach drei Runden von Fragen und Diskussion, identifizierte das Forum 14 Forschungsziele, die als "sehr wichtig“ oder „wichtig“ von mindestens 12 der 14 Experten (80 \% wurden allgemein für einen Schwellenwert des Konsens verwendet). Die Resultate dieser Arbeit sollen der zukünftigen Forschung und den Bemühungen zur Finanzierung in der Arboristik und der urbanen Forstwirtschaft helfen, besser zu fokussieren.

Resumen. Los árboles urbanos son a la vez un activo y un costo para los municipios. Las investigaciones anteriores se han centrado en gran medida en cuantificar y valorar los beneficios sociales, económicos y ambientales que proporcionan los árboles en las zonas urbanas. Relativamente pocos estudios se han centrado en definir el nivel apropiado de cuidado de los árboles (costos o entradas) para el mantenimiento de la salud e integridad estructural del árbol y el pasivo potencial resultante de manera eficiente. Los días 18 a 20 de marzo de 2015, la Sociedad Internacional de Arboricultura reunió a un panel de expertos de investigación y de la industria para un simposio cumbre de investigación titulado: "Los Costos de No Mantener los Árboles". En las semanas previas a la cumbre se inició la técnica Delphi para ayudar a construir el consenso sobre cuestiones clave de investigación relacionadas con los aspectos económicos de los árboles y su cuidado. Después de tres iteraciones de preguntas y discusión, el panel identificó 14 temas de investigación que se consideraban "muy importantes" o "importantes" por al menos 12 de los 14 panelistas expertos (siendo el $80 \%$ un umbral de uso común para el consenso). Los resultados de este trabajo tienen la intención de ayudar a centrar los futuros esfuerzos de investigación y financiación en la arboricultura y la dasonomía urbana. 